\title{
"We are the memory representation of our parents": Intergenerational legacies of genocide among descendants of rape survivors in Rwanda
}

\author{
Marie Grâce Kagoyire, MPH*, Annemiek Richters**,***
}

\section{Key points of interest}

- Women traumatized by genocidal rape in Rwanda leave a legacy of pain and suffering to their children. A specific feature of children born as a result of genocide-rape is their struggle with self-identity as a descendant of both an unknown perpetrator father and a mother who is a victim of rape.

- Group interventions can empower youth, enabling them to develop a sense of self-worth, self-acceptance, self-reliance and new social connections. This can give them hope for the future and confidence in the present.

\section{Abstract \\ Introduction: The 1994 genocide against the Tutsi in Rwanda subjected thousands of women to rape as part of a range of other genocidal atrocities. This article explores what it means in everyday life to be a descendant of such mothers. Methods: A qualitative study was conducted in eastern Rwanda. The twelve}

*) Duhumurizanye Iwacu Rwanda

$\star \star)$ Amsterdam Institute for Social Science Research,the Netherlands. Prof. Emeritus.

$\star \star \star)$ Leiden University Medical Center, the Netherlands

Correspondence to: kagograce@gmail.com respondents, all descendants of genocide-rape survivor mothers, participated in focus group discussions and semi-structured interviews. Topics focused on different aspects of the intergenerational transmission of trauma and the mitigation of this transmission by the psychosocial support from which their mothers benefited. The phenomenological method as developed by Giorgi (2012) was used to analyze the transcripts. Findings: All respondents, regardless of their birth circumstances, are marked by growing up with a severely traumatized mother. Children conceived during rape are specifically marked by the absence of a perpetrator father unknown to them, the others by the lack of many (extended) family members. They all benefited from the psychosocial support provided to their mothers. Discussion: Genocidal rape causes specific kinds of suffering and specific identity problems for the children born as a consequence of genocide-rape. However, even if the children were not conceived during the rape, their level of suffering is similar. Conclusion: The effects of the intergenerational transmission of trauma related to the 1994 genocide against the Tutsi in Rwanda should be recognized among all youth deeply affected by it. Appropriate policies and programs should be designed and implemented to moderate the effects and strengthen resilience to ensure a peaceful future on an 
individual, interpersonal, and inter-relational community level.

Keywords: Genocide, rape, trauma transmission, intergenerational, Rwanda

"About the history, I always forced my mother to tell me our family history; what happened to her, the death of her husband during the genocide, and how all family members were finished off. But what I mostly focus on is asking her who my father is. She has refused to tell me. I started to ask her this when I was in primary five. The teacher inquired about my age and whether my father was still alive. I said 'no, my father died during the genocide'. My school mates laughed at me. They said, that cannot be, since the genocide happened in 1994, while I was born after it. I felt challenged and spent the whole day crying there at school. I went back home before finishing class. When I reached home, I did my household chores as usual, but with anger. When it was around one in the morning, I woke up. I was sleeping in the same room as my mother. I sat on my bed and asked her 'who is my father?', stressing that it was time to disclose this to me. My mother responded that I should not ask her such a thing. She said 'I gave birth to you, I am here, I raised you, and you are growing up in a good way. Why should you ask that question?' I told her what happened at school. In response she said that my father is a worthless person, that she lost all her children except for the one she had carried on her back during the genocide and then that man raped her after the genocide. But she told me that in a superficial way. We both cried and our discussion ended up with tears."

(Estonia, 19-years-old)

\section{Introduction}

The quote above is an excerpt of the story of Estonia, ${ }^{1}$ a young Rwandan woman born of rape. Her mother is one of the nineteen women who survived the 1994 genocide against the Tutsi in Rwanda and who previously shared their life history with the research team. All stories were published in a booklet in Kinyarwanda (Kagoyire et al., 2013) and distributed widely. ${ }^{2}$ Following this publication, regular follow-up meetings were held-eighteen between April 2014 and April 2018 - with fifteen of the nineteen women. ${ }^{3}$ All fifteen women had experienced genocide-rape as one of the atrocities they had been subjected to. The initial goals of these meetings were to: monitor whether the publication of the women's life histories had any adverse repercussions for them; monitor the impact of the more than two-year long process of narrating their stories (20102013); and assess their participation in a sociotherapy group (cf. Richters et al., 2010), providing them with psychosocial support on the quality of their lives at the start of this process. Each year in April, prior to the annual genocide commemoration week, ${ }^{4}$ a meeting to emotionally prepare the women for the mourning process was held. Occasionally, details on a specific theme raised by the women in a previous meeting was discussed.

1 All names used in this article are pseudonyms.

2 Ten of these stories, all of them by women with experiences of genocidal rape, were published one year later in abbreviated form in English translation in this journal (Richters \& Kagoyire 2014).

3 The other four women only joined one or a few meetings at the start. Two had not experienced genocidal rape, one did not want her rape experience published, and another woman died shortly after the 2013 publication of life histories.

4 The commemoration period runs from April 7th up to the end of July 31 st. The first week is the most intense in terms of organized activities. 
In the meetings the women repeatedly expressed concerns about their children regarding: children dropping out of school and wandering around; children becoming street children; children raising questions about the genocide and family history that they did not know how to answer; and children becoming traumatized, angry, isolating themselves or rebellious. One of the women stated spontaneously in the meeting of May 2016, "Children who were small during the genocide, or who were in the womb of their mother during the genocide or who were born shortly after the genocide; it is in their blood." ${ }^{5}$ Hearing similar kinds of observations in this same meeting, and the two following ones, informed the decision (in the meeting held in August 2016) to specifically focus on the issue of children's inheritance of their mothers' genociderelated suffering. One woman in that meeting responded to the above statement with:

"I would say the same. Children in their mothers' womb during genocide or small during the genocide, when born and growing up, they have no brother, no uncles, no aunts, all have been killed during genocide. They grew up through suffering and sadness. When they lack something, they can attribute it to the genocide. My daughter does not regularly attend school, she cannot succeed like others. It is in their heart/brain. They continue to think about the genocide. There is no escape. They experience the consequences. It is incorporated somewhere, it sticks in their heart. We try to teach them that they should get reconciled. They do not agree. It remains in them. Scars are still there."

5 This immediately brought to mind what Hirsch (2012, p.32) writes on descendants of Holocaust survivors. "Loss of family, home or a sense of belonging and safety in the world "bleed" from one generation to the next” (p. 34). (quotation marks in the original).
These and similar contributions to our discussion on the theme of 'intergenerational transmission of trauma' motivated the decision to speak to the children themselves about their lives, specifically how their lives are impacted by what their mothers went through in terms of traumatic experiences, including the experience of genocidal rape. Acknowledging that the concept of intergenerational transmission of trauma is somewhat contested in the literature (cf. Kellerman 2001), the following definition is used-'the direct transmission of trauma symptoms from parent to child as well as the effects of trauma-informed parenting on the development of the child'.

The exact number of women raped, who were often gang-raped multiple times, during the genocide in Rwanda, or the children born of genocidal rape, will never be known. The stigma and shame that cause women's and children's reluctance to disclose their experiences are major reasons for this. Perhaps the most accurate estimate of the number of women that were raped during the genocide is the one made by Bijleveld and colleagues (2009). Their lower estimation finds that there were over 350,000 female rape victims, of which only 50,000 may have survived. However, this estimate hinges on a mortality estimate of 800,000 people. Figures collected in 2000 by the Rwandan Ministry of Local Government documented a minimum of 934,218 deaths (MINALOC 2004), which implies that the number of female rape survivors is likely to be higher than 50,000. Nowrojee (1996) estimated that between 2,000 and 5,000 children were born of genocide-rape. More recent estimates by the Survivors Fund (2014), a Non Governmental Organisation (NGO) supporting children born as a result of rape in Rwanda, identified the figure to 
be $20,000 .{ }^{6}$ The total number of children who grew up with mothers who experienced genocidal rape is not available but may be three to five times this figure.

Over recent decades, increasing attention has been given to sexual violence as an act of war and genocide. Children born of genocide-rape have gained significant attention; while children of women who experienced genocide-rape, but were not conceived during this rape, have been neglected. One of the first to claim forced impregnation being a genocidal act was Carpenter (2000), who highlighted the distinctive vulnerability of children born as a consequence of rape in conflict zones. Carpenter advocated for the human rights of these children and proper care for them (cf. Carpenter, 2007, 2010). Regarding sexual violence during the 1994 genocide in Rwanda, the focus was also primarily on the women raped (cf. Amnesty International 2004; Nowrojee 1996), while attention on the plight of their children born of rape gradually followed, primarily in newspaper articles at first (e.g. Wax, 2004) and published interviews (e.g. Torgovnik, 2008) and, subsequently, in scholarly work, such as unpublished student theses (e.g. Umulisa 2009), book chapters (e.g. Mukangendo, 2007) and articles (e.g. Banyanga et al., 2017, Denov et al., 2017 Eramian \& Denov 2018, Hogwood et al., 2014 Hogwood et al., 2017, Katengwa 2014 Nikuze 2013).

The outcomes of the discussions held with the fifteen women and interactions with a selection of their children were reflected upon before writing this article. It was concluded that limiting the article

6 https://survivors-fund.org.uk/awareness-raising/ children-of-rape/ to children born of rape would fail to do justice to what was shared by the mothers and their children. Writing about the 'intergenerational fallout from genocidal rape', Denov et al. (2017) argue that this fallout "has been largely overlooked and, in particular, the voices and perspectives of those directly implicated - children born of genocidal rape- have been neglected and ignored." (p. 4). On the contrary, we argue that researchers before us have studied the problems of these children, at least those in Rwanda, in some depth. This paper therefore focuses on what it means to be born as a result of a 'genocide-rape survivor mother' (cf. Zraly et al., 2013) and grow up with her. The specific challenges that children born of rape face in their daily lives, as compared with children of mothers who were raped during the genocide, but who did not fall pregnant as a consequence, are explored.

\section{Methods}

Twelve of the fifteen women with whom we regularly interacted after the publication of their life histories had a child between the age of 18-25 years old. Thus the total sample size was twelve and all were born shortly before, during, or soon after the genocide. ${ }^{7}$ Respondents were recruited through their mothers, who were asked by phone to contact their child and request that they speak with the first author. The next available child falling within the chosen age range was recruited to participate in the three cases where a selected child was not available. ${ }^{8}$

7 The terms 'young people, 'youngsters', 'descendants' and 'children' are utilized throughout this article as a reference to our respondents: descendants of genocide-rape survivor mothers.

8 Socio-demographic and biographic details of all respondents can be found as additional material on the Torture Journal's website: https://tidsskrift. 
The sample comprised seven females and five males. Nine were in secondary school and the remaining three dropped out.

According to their mothers, five were born of rape. Two of these five children openly shared this. Three of the five children were born of rape during the genocide and two during the aftermath. ${ }^{9}$ One of the other seven respondents was born during the massacres preceding the genocide, in Bugesera District in 1992 and another was born during the genocide itself. Both of their fathers were killed during the genocide. Two other respondents were born of mothers who got married soon after the genocide and lost their husbands, due to death by natural causes after a few years of cohabitation, while the remaining three were born after the genocide from parents who are still alive. Six respondents live with their widowed mothers. Five respondents live with their mother and her husband, while one woman did not know the whereabouts of her husband and the father of her children.

The study started in 2017 with two focus group discussions (FGDs) which were attended by ten of the twelve youngsters. The two additional ones joined the study in its subsequent phase of individual semistructured interviews (IIs). Throughout the study period, contact with individual respondents was maintained through phone or home visits and three informal meetings with a selection of respondents, culminating in a more formal FGD in 2018. All FGDs, interviews and informal meetings were undertaken in places where

$\mathrm{dk} /$ torture-journal/issue/archive

9 Even though the genocide had officially ended in July 1994, in its immediate aftermath the population found itself in dire living circumstances while, since genocide perpetrators were still around, the security was not yet fully ensured. it was expected that respondents would feel safe. Respondents were informed that their confidentiality would be guaranteed and written informed consent forms were provided, read and signed by the respondents prior to the start of FGDs and interviews. Rwanda National Ethics Committee granted approval prior to data collection (No.111/RNEC/2017).

The main topics addressed in the FGDs and interviews included parentchild communication in the family, parental genocide experiences and its effects on descendants, the meaning of being born of a genocide-rape survivor mother as well as the indirect benefit from a mother's participation in a sociotherapy group. The FGDs lasted approximately one hour and interviews lasted approximately one hour and a half.

Both FGDs and interviews were conducted in Kinyarwanda, audio recorded, and transcribed verbatim in English. The transcripts were analysed following the phenomenological method as developed by Giorgi (2012), which involves entering into the phenomenal world of the respondents to see how they situate themselves in their world. A coding framework was developed based on the emerging themes and a codebook was drafted. Next to the codebook, a simple table was designed to summarize the important points raised in response to each of the topics addressed in the FGDs and interviews. Subsequently, similar themes were regrouped. In order to keep the original meaning of the text, some extracts were given to Kinyarwanda-speaking colleagues for cross-checking through backtranslation.

\section{Findings}

The findings refer to different aspects of the effects of the transmission of trauma to respondents by their mothers. The first 
theme covers descendants' experiences with growing up under stress, abuse and frustration, and their responses to that. The second addresses the children's experience of living in a void regarding the family past, which they desperately try to fill. However, when this void does get filled in, the distress of not knowing the family past is replaced by other distresses (theme three). To be born and raised under difficult circumstances makes descendants struggle with their identity and how to represent themselves, which is theme number four. The reversibility of at least some of the negative effects of trauma transmission falls under theme five. Similarities and differences between life experiences of children born of rape and those who are not are discussed.

Theme one: Growing up under stress, abuse and frustration

Most respondents reported that they were born in "the bad period," which they refer to as a period of unhappiness when the wounds of their parents were still fresh and their parents "had nothing," since all of their possessions were destroyed during the genocide. A mother who survived the genocide exposed her children to genocide-related emotional suffering, which was particularly pronounced when living with her. Almost all children also reported facing physical and verbal abuse from their mothers.

Some respondents repeatedly heard their parents calling absent people, unknown to the children themselves, as well as talking about their genocide experiences. This predominately occurred during the annual genocide commemoration period, "the dark time" within the families. During this time, before their participation in sociotherapy, the mothers suffered from severe trauma crises. Some isolated themselves, looked anxious, and struggled to hide their emotional pain from their children, but the changes observed in the mothers automatically animated changes in their children. The commemoration period was stressful for the mothers, which also became stressful for their children, as illustrated below:

"At the time, I was saddened by the way my mother was. I used to feel upset when she got angry and cried. I was very anxious wondering what I could do if my mother would become a mad person. Since she got healed, I feel safer. When she was crying, I felt there was nothing I could do. I became stressed out and ran away or called my siblings so that they would come to my rescue. It makes you feeling afraid when you see your mother crying."

(Madeleine, II 2017)

Besides the trauma crises, the youngsters communicated that they were also exposed to the howls and screams of the nightmares experienced by their mothers. These nightmares focused mostly on the mothers' genocide hardships, referred to by respondents as a mother's "Calvary pathway," during the genocide. As a consequence of rape, Estonia was born in 1998 and is the youngest child of Berthilde. During the genocide, Berthilde's house had been destroyed, her husband and six children had been killed, and Berthilde herself had been gang raped more than once. She was raped again three years later when living in a dilapidated house. Estonia, like a few other respondents, suffered from her mother consuming alcohol as a strategy for coping with her painful past. Her aggressive behavior resulted in Estonia being abused. "Each morning she would sell something in order to get alcohol ... When drunk, she was always angry. She insulted me all the time. She could not feel happy with me as her child!," 
Estonia shared. Estonia and her mother developed a complicated relationship: "It was difficult. ... When my mother insulted me when drunk, I was sad. I would then remind her that she does not love me, that I am a bastard child. I could spend the whole night crying. You could find my bed sheets being wet because of tears." (Estonia, II 2017)

It was mostly through exposure to their mothers' nightmares, trauma crises and aggressive behavior that children initially learned about their mothers' painful genocide experiences. What they learned was a source of worry and frustration for them, especially when they did not know how to help their mothers emotionally.

Children born of rape reported particular challenges. Relative to the other respondents, they appeared to suffer more from verbal harassment as well as avoidance by their own mothers. Mostly during the commemoration period, they were warned to stay away from their mothers and be careful. In order to cope with this stressful period, the children kept quiet and withdrew from their mothers to avoid inflicting pain. Although some children were kept at a distance more than others, almost all experienced the isolation of the mother and felt considerable concern regarding their mother's emotional pain and related behaviors. This often resulted in role reversal. Instead of mothers taking care of their children, children took care of their mothers and comforted them.

Although children are affected by being born into these challenging conditions, and have embodied their mother's suffering, descendants communicated their commitment to working hard in their everyday activities, such as at school or at work. They strived for a successful future for their families and to foster positivity amongst family members, as demonstrated below.
"For instance, I am among the top students in our class. I wish to make the difference. I wish to reach far so that I cover that emptiness caused by my father's family which has caused my mother to suffer. By the fact that my father's family hates my mother, it motivates me to work hard so that I will make my mother happy."

(Didi, II 2017)

Solange shared that mothers see their children (not born of rape) in the image of their lost relatives. Their parents may give them the names of those relatives. This causes the descendants to feel as a (historical) 'symbol' or 'memory representation' for their families, which may be a burden for them. These youths live under the stress of performing well in whatever they do, so that they do not disappoint their parents who, despite being neglectful, do all they can to provide for them and have considerable ambitions for their children. Becoming a good replacement for the mother's lost family member is an additional factor motivating youth to work hard so that they do not fall short of parental expectations. Respondents wished that their mothers no longer reflected back on their painful past. As stated by many of them, their aim is preventing their mothers from being overwhelmed by grief at the death of their loved ones. How one may feel as 'memory representation' is expressed by Solange as follows:

"My father used to call me by the name of his family's last born. They see theirs through ourselves. They give us names of their loved ones that perished during the genocide. This means that they physically disconnected from those killed but at the same time are still connected to them, carrying them in their hearts and souls. They don't forget them, theirs never perish. So we work hard so that we don't damage those names of theirs 
we are given.... They consider us as their representations or symbols. They feel theirs have gone but are still alive through us." (Solange, FGD 2018)

Children born of rape did not speak about 'memory representation'; however, the mothers themselves often viewed their children as living representations of their rapists.

Theme two: Questioning, silencing and fragmented stories

The mother-child dynamics, as illustrated in the Estonia's quotation introducing this article, is dominated both by endless questions about the family past from the side of the youth, and by silence, intimidation and fragmented stories in response to those questions from the mothers. Even when information is shared by the mother, the past remains difficult to understand. There is a lack of clarity among respondents about the death of family members and why family members were targeted during the genocide. For youth born of rape, the questions which most concern them are about their father, especially his name, current whereabouts and, sometimes, his looks. Silence and fragmented stories were found in all respondents' families. Asia, whose mother was raped during the genocide while hiding in the bush and who is now living with her grandmother and her own child, articulated it as follows:

"Before, when I brought the topic about my father's family up, my mum's mood would change. It was not easy for her, she could not tell me. I could observe that she was sad, looking like she wanted to cry and that she hid something from me. When she changed emotionally in that way, I would stop asking. I felt a lot of anger, was sad, and I could not understand why my mother did not want to tell me."

(Asia, II 2017)
Gerard was not conceived during rape but his mother, who was still single when she was raped, had a similar experience:

"But sometimes when I request her to tell me the whereabouts of our family members, she may change her mood, she gets sad, her look changes and she keeps silent. You continue to ask but she does not reply and then you stop asking."

(Gerard, II 2017)

The children born of rape were eager to know their paternal genealogy. The children not born of rape mostly focussed on the survival strategies of their mothers, the reason why they do not have extended family members like other children (referring to children not descending from genocide survivor families), how their mothers survived while others were killed, and the biographic data of the perpetrators. Madeleine, born during the genocide when her mother was hiding in the marshland, explains why youths question the past as follows:

"For me, I think every child born after the genocide wishes to know that. It should be told to us because we were not alive; some were there but were not consciously following what was happening. Others were still in the wombs of their mothers or a mother gave birth during that time. So, as a child who did not experience that consciously, you wonder how it was, how a pregnant mother could run away. You ask yourself how she managed to survive and why they did not kill her." (Madeleine, II 2017)

Almost all respondents considered themselves as a generation that struggles to find clear and full information about the family past, although they may never have full access to their family history. They are unsatisfied because they are, consequently, unable to share their family history with their own future children. However, they recognize 
that their questions may remind their mothers of the past. Their mother's inability to communicate their suffering in words is perceived by the children as a mechanism to protect them from the suffering that a sharing of the past may provoke.

Theme three: Emotional pain and relief related to disclosure of the mother's past

While respondents reported a lack of information about parental past experiences and desperately wanted that information, those children who did gain access to (some of) this information experienced conflicting feelings - they were both troubled and relieved at the same time. For example, the knowledge galvanized raised feelings of revenge and hate towards perpetrator families, while the recent positive changes in attitudes and behavior of the mothers, which were linked to the psychosocial support they had received (see also below), were depicted as a kind of relief. Madeleine shared some of the negative effects of learning about her mother's past:

"When you hear a hurting story about your family, you cannot forget it. The brain keeps it and such thoughts come back into your mind sometimes. We as young people, we may even feel unsatisfied in our lives because of the wounds our parents have. Children do not forget easily, so they may grow up being traumatized."

(Madeleine, II 2017)

Differences in emotional pain as a result of learning about their own mother's hardships were also reported. While youth not born of rape developed feelings of revenge against the perpetrator, those born of rape expressed that they could not forgive the rapist: "I feel that in case I would come across the person who wronged my mother, I cannot forgive him because to me he is of no use. I do not wish to see him." (Asia, II 2017). Another negative effect of the emotional pain related to knowing the painful past experiences of their mothers caused the youth to feel discouraged from maintaining connections with others, particularly their peers whose parents belonged to the perpetrator's ethnic group.

"After knowing my mother was cut during the genocide, I felt discouraged to talk to other people. I wondered what I can do if I meet him (the perpetrator). When I think about that I feel angry and stop talking to whomever."

(Julia, II 2017)

Despite differences in the child's experiences with a genocide-rape survivor mother and in channels through which children learned about their mothers' experiences, distress when learning about the rape of one's own mother was a shared cause of anguish among respondents. After hearing or reading about their mother's rape, the following symptoms were commonly reported: stomach aches, headaches, lack and/or loss of concentration, and sadness. All youth also communicated that when their mothers felt bad, they too felt unpleasant feelings.

Although mothers at times still isolate themselves or still force their children, specifically those born of rape, to be far away from them, children developed an intensified attachment to their mothers after disclosure of her past. They reported feeling even more responsibility to intervene and care when the mother was not feeling well:

"When she comes to me crying, I let her lie on my legs and, let her cry and do whatever she wants. It happened in the past that my mother locked herself in her room and cried. ... When she did that, I would brutally knock on her door until she opened. I could not leave the place before she stopped crying."

(Alicia, II 2017)

In addition, youth reported that once their mothers had revealed 'the whole story', their 
perceptions changed. The depiction of their mothers as wicked and immoral, due in part to the mothers concealing how they survived or conceived them, were replaced with more sensitive portrayals as vulnerable mothers that needed understanding and sympathy.

\section{Theme four: Self-representation, identity and} related challenges

During a FGD Solange stated, "those who were born from perpetrator families are ashamed. I feel I am proud of descending from a parent who did not commit the atrocities." Indeed, almost all of the respondents reported that children born of rape have identity problems, especially those children born of rape. The latter are caught in the trap of being born from a perpetrator father and a victim mother. Although there is a blood relationship between a rapist and a child conceived by him, that child considers the father as a source of their mother's suffering. He caused him or her to be born; they were not planned by their mother as her other children were. The image Estonia had of her father stems from what her mother told her- "a man without value, like nothing, a rascal wandering around, a dog."

Shame is the everyday suffering of children born of rape. Acknowledging the wrongdoings of their fathers while sympathising with their own mother is a challenge. Patel, similarly to a few other children born of rape, tries to suppress his thoughts about his father's crimes, "those children (born of rape) don't like to think that their fathers committed the genocide; they feel and identify as Tutsi instead." Distancing themselves from a perpetrator's identity and overidentifying themselves with their vulnerable mothers is one of their ways of coping with the shame and stigma associated with being born of a perpetrator parent. Patel continued, "I am thankful to God that I was born from a survivor mother. You cannot easily connect to children from génocidaire families."

Changing the date of birth is another coping strategy among children born of rape. This way they try to conceal their linkage to a perpetrator father. This is the case with Julia, whose mother had revealed this while telling her life history that Julia had been born of rape, and which had caused the separation from her husband. When the interviewer inquired what the consequences might be of a mother's genocide experiences for the life of young children, Julia responded:

"There is depression. When you discuss with your mother and she tells you that the man you call your father is not your real father and that you were born of genocide-rape, I feel I am alone and get depressed." (Julia, FGD 2017)

However, while filling in biographic information later, Julia wrote 1998 as the year of her birth, which contradicts what she had said before. Like Estonia, Julia may have changed her year of birth so she could be viewed as a child of her mother's husband. Estonia prefers to be enrolled under the name of her mother's late husband ${ }^{10}$ as she had already registered him as her own father, although he was killed three years before Estonia's birth.

According to a few respondents, being born of rape is associated with many challenges such as: having no family; difficulty finding the name of one's own father, especially when required for administrative purposes; harassment by peers and husbands of their mothers; endless thoughts; sadness; trauma; and having neverending questions for one's mother. These

10 The husband of Estonia's mother was killed during the 1994 genocide and Estonia was born in 1998 as shared above. 
everyday challenges may affect their school performance. Respondents also feared that the lack of information about one's own genealogy may lead to accidental incest, something considered as an atrocity by the respondents themselves:

"Knowing my origin helps me to know also my siblings and relatives. I may study with a peer and befriend him or her. Imagine if we get married and later find out we are siblings! That would be a scandal."

(Solange, FGD 2018)

In contrast to children born of rape, respondents born of a Tutsi father testified that they feel proud of being a child of a Tutsi mother and belonging to parents who did not commit the atrocities. They argue that they are not ashamed of their parents, unlike the youth of their age who were conceived by perpetrator fathers. However, Alicia, who was not born of rape, challenged this narrative. She did not want to belong to any ethnic group because that belonging caused conflicts in the past. Each category of youth has its specificities, but there are also similarities among descendants whose mothers survived genocide-rape. Almost all wish to belong to the ethnic group that was victimized during the genocide. Although youth born of rape did not openly share how uncomfortable they are with their genealogy and some of them wanted to know their father, they were also proud of having a Tutsi mother. The latter serves as protection against stigma as a child of a génocidaire and a way of coping with the emptiness of not having a known father.

\section{Theme five: Change due to transmission of} positive parenting

Over recent years, the mother-child relationship changed for the better, which the children and mothers largely attributed to sociotherapy. Regarding this impact, their children cannot distinguish between the effects of participation in sociotherapy, 'the story project' and the follow-up meetings with their mothers. Respondents speak primarily about the benefits of sociotherapy, while we attribute the changes to all three.

When asked to compare the life at home before and after their mothers' participation in sociotherapy, children reported perceiving sociotherapy as a place in which mothers share their sorrow and develop hope for the future. According to them, changes in their mother's life helped them to feel a sense of release. Their mother's empowerment made them benefit from love, become involved in family decision making, share joy with their mothers, benefit from improvement in mother-child communication and relationships, experience less worry about the mother's suffering, have hope for the future, and perform better in school. Some respondents, who had feelings of revenge, reported that they feel they can now forgive the family's perpetrator. Due to advice received from their mothers and the mothers' increased self-confidence, their own self-confidence increased. Their mother's smile gave hope to them as their children. The change John observed in his mother is quite representative of what other respondents experienced in terms of change:

"I think that if my mother had continued to be like she was before joining sociotherapy, my life would not be like I am today. It was highly possible that I would have become an isolated young person. My marks might have decreased and I think I could have developed a heart attack due to thinking too much about the suffering of my mother. By the fact that my mother has changed and became strong, I stopped getting worried about her and I feel at ease wherever I am because of the hope she got back. I think I would not be the fohn of 
today if there had not been changes into my mother's life. ... Since she started to join sociotherapy, she also started talking to me. She could answer the questions I used to ask her about the history. She started to create hope inside me, ${ }^{11}$ that will enable me to succeed in life. When she tells me that I can study and become a strong man who can be important for the whole family in the future or when she is advising me and when I observe how she changed, I do believe in what she tells me."

(John, II 2017)

For the children born of rape, the main benefits were learning their birth circumstances and acceptance by their own mother as their own child, as testified by Estonia. After learning that she was born of rape, due to improvements in her mother, her mother was able to accept her as her own child and became proud of her:

"For me, I think in sociotherapy, they do something like repenting. It seems they tell everything they have in their hearts. She used to cry when we came back on the history but now tears have reduced. She does no longer stop talking to me. In addition, she now trusts me. ... She started to be happy and proud of me. One could find us in the house laughing loudly while being the two of us. She started for instance to invite me to go to the market together and help her to make choices on the things she wished to buy whereas this did not happen in the past."

(Estonia, II 2017)

11 A similar emotional pattern of intention to create hope and courage in their children has been identified among mothers by Zraly et. al (2013) in their study among Rwandan genocide-rape survivors. These mothers did not benefit from an intervention, like sociotherapy, that supports this process.
The common benefits of this positive parenting experienced by the youth include: improved school performance, happiness, restoration of family history, hope for the future, and confidence in the present.

\section{Discussion}

Findings indicate that the chronic trauma of genocide-rape survivor mothers in Rwanda had considerable effects on their descendants. Their children grew up in an ambivalent mother-child relationship, as 'memory representations' for their mothers, either as representations of loved ones who were killed or of the rapists who impregnated their mothers. They also gained remarkable resilience from their mothers, particularly after their mothers' participation in sociotherapy, which was enhanced by self-generated resilience. This mixture of suffering and resilience transmitted to the children resembles what other studies found among offspring of survivors of war and genocide elsewhere (cf. Braga et al., 2012; Gobodo-Madikizela, 2016).

Our respondents born of genocidal rape face similar challenges as those identified in previous studies on children born of genocidal rape in Rwanda (e.g. Denov et al., 2017, Eramian and Denov 2018, Hogwood 2017). They struggle with a specific kind of identity problem and experience a lack of belonging to their survivor mothers for as long as their mothers continue to suffer from their own traumatic memories as well as nonrecognition by the perpetrator father. This kind of identity problem may result in "difficulties of being loved by, or loving, someone else, which may create conflict in their future marriage." (Sarabwe et al., 2018, p.19). In contrast with other studies, this study also included children born of genocide-rape survivor mothers, 
but not born as a consequence of the rape their mothers suffered. This enabled the identification of differences and similarities between both groups of descendants. In studies of women who experienced war and genocide-rape, the trauma of rape is often singled out as the most important component of women's suffering, the vortex that captures most of their inner energy, while their stories of pain and survival comprise so much more than the experience of rape (cf. Richters and Kagoyire, 2014). Similarly, we found that in studies of children born of rape, this rape is singled out as the most challenging of all the difficulties that these children have to cope with in their lives. However, this study shows that there are also other common problems, mostly related to growing up with a mother severely traumatized by her genocide experiences, the lack of family members to support her, and the struggle to make ends meet in daily life.

All respondents experienced feelings of uprootedness in their lives, a lack of information about family members who perished during the genocide, parental withdrawal and isolation, especially during the annual commemoration period, when growing up in a situation of abuse and frustration due to their mothers' trauma. What is different between respondents born of rape and those who are not? The former struggle to distance themselves from their fathers' identity and over-identify with their mothers' identity. The latter felt proud of their birth in an ethnic group that was victimized.

As Hogwood et al. (2017) point out, disclosure by mothers of their genocide history had, at least initially, a negative impact on the emotional life of children born of rape. The impact consisted of intrusive thoughts, loneliness, anger, sorrow, hopelessness, etc. Our study found that it was not only emotionally painful for those born of rape, but for all respondents to learn about the rape of their mother. It is presumed that most respondents are informed of their mother's rape experience, even though the one male, in contrast to the two out of four females (born of rape), refrained from openly admitting this. Like other group interventions (e.g. Banyangara et al., 2017; Hogwood, 2014), sociotherapy facilitated disclosure by improving parentchild communication and relationships. The mothers' empowerment, due to sociotherapy, contributed to mitigating the negative effects of disclosure and thus, indirectly, contributed to the wellbeing of their children.

Hogwood et al. (2017) find that, after discovering that children are born of rape, females were neutral regarding their perpetrator father while males were angry and aggressive. However, in the sample studied here, two female respondents reported that they were angry with their father even though they were receptive to getting to know him. This admission of feelings of anger may be related to the positive perceptions that respondents have towards sociotherapy.

The respondents perceived FGDs as confidential and a safe space, which cultivated a strong sense of trust.

Respondents were generally open with regard to their emotions. However, respondents stressed the relevance of sociotherapy for themselves and other youth. As expressed by Madeleine (II 2017), "I would like to request that you organise sociotherapy for us young people so that we benefit as our mothers benefited from it." The youth appreciated the sharing of their hardships with each other and learning from one another in the FGDs they had participated in. 


\section{Conclusion}

Due to the small the size, our findings cannot be considered as representative of what all Rwandan young people experience in terms of what they get transmitted from mothers who were severely traumatized by genocidal rape and other traumatizing genocide experiences. Nevertheless, we draw some conclusions that may be applicable more widely.

In this article the focus was limited to children born of mothers who survived genocidal rape. Remaining within this focus, we recommend that, when aiming at long-term peace, the process of societal reconstruction in post-conflict contexts must be more responsive to intergenerational realities of war and genocidal rape, including the invisibility of children born of wartime and genocide-rape. In this regard, even though youth born of rape have their specific problems, especially identity problems, all those descending from genocide-rape survivors are at high risk of intergenerational transmission of trauma. There is a need to support the mothers, as well as their young descendants. This has also been recommended by other researchers, specifically for children born of rape (e.g. Banyanga, 2017; Denov, 2015; Eramian and Denov, 2018; Hogwood, 2014, 2017). Such support, if comprehensive, can to reduce the descendants' vulnerability and enable them to better cope with their identity and the other problems highlighted in this article.

Children born of genocidal rape survivor mothers are not the only children in Rwanda who suffer from the intergenerational fallout of genocide atrocities and would benefit from group participation in safe spaces to share their experiences with this fallout. Other children include, but are not limited to, children of ethnically mixed marriages (Doná 2012) and children of perpetrator families (Rutayisire \& Richters, 2014, 418419). Our experience with sociotherapy, as an example of psychosocial support for parents and children, informs our belief that that this support may empower parents in their parenting role, as well as youths who are negatively affected by genocide legacies. They can develop self-pride, self-acceptance, self-reliance and new social connections and subsequently gain hope for and confidence in the future. This kind of support may also mitigate intergenerational transmission of genocide legacies that could incite future violence and empower youth to contribute to peaceful communities and the prevention of another cycle of violence instead.

\section{Acknowledgements}

Many thanks are due to all participants in this study and their mothers. We also thank the reviewers of the manuscript and the editorial team of this journal for their support.

\section{References}

Amnesty International (2004). Rwanda: "Marked for Death," Rape Survivors Living with HIVIAIDS in Rwanda. AI Index: AFR 47/007/2004.

Banyanga, J. D., Björkqvist, K., \& Österman, K. (2017). The trauma of women who were raped and children who were born as a result of rape during the Rwandan genocide: Cases from the Rwandan diaspora. Pyrex fournal of African Studies and Development, 3(4), 31-39. https://doi.org/1 $0.1080 / 23311908.2017 .1333244$

Bijleveld, C., Morssinkhof, A., \& Smeulers, A. (2009). Counting the countless rape victimization during the Rwandan genocide. International Criminal Fustice Review, 19(2), 208-224. doi: 10.1177/1057567709335391

Braga, L. L., Mello, M. F., \& Fiks, J. P. (2012). Transgenerational transmission of trauma and resilience: A qualitative study with Brazilian offspring of Holocaust survivors. $B M C$ Psychiatry, 12(1), 134. doi: 0.1186/1471244X-12-134

Carpenter, R. C. (2000). Surfacing children: Limitations of genocidal rape discourse. Human Rights Quarterly, 22(2), 428-477. doi: 10.1353/ hrq. 2000.0020 
Carpenter R.C. (2010). Forgetting Children Born of War: Setting the Human Rights Agenda in Bosnia and Beyond. New York: Columbia University Press. DOI: $10.7312 /$ carp 15130

Carpenter, R. C. (ed.) (2007). Born of War: Protecting Children of Sexual Violence Survivors in Conflict Zones. San Francisco, CA: Kumarian Press. https://doi.org/10.1080/17441691003641807

Denov, M., Woolner, L., Bahati, J.P. Nsuki, P., \& Shyaka, O.B. (2017). The intergenerational legacy of genocidal rape: The realities and perspectives of children born of the Rwandan genocide. Fournal of Interpersonal Violence, 1-22. doi: 10.1177/0886260517708407

Doná, G. (2012). Being young and of mixed ethnicity in Rwanda. Forced Migration Review, 40(7), 16-17.

Eramian, L. \& Denov, M. (2018). Is it always good to talk? The paradoxes of truth-telling by Rwandan youth born of rape committed during the genocide. Fournal of Genocide Research, 20(3), 372391. doi: $10.1521 /$ psyc.64.3.256.18464

Giorgi, A. (2012). The descriptive phenomenological psychological method. Fournal of Phenomenological Psychology, 43(1), 3-12. doi: $10.1163 / 156916212$ X632934

Gobodo-Madikizela, P. (ed.) (2016). Breaking Intergenerational Cycles Of Repetition: A Global Dialogue on Historical Trauma and Memory. Opladen: Barbara Budrich Publishers.

Hirsch, M. (2012). The Generation of Postmemory: Writing And Visual Culture After The Holocaust. New York: Columbia University Press.

Hogwood, J., Auerbach, C. Munderere, S., \& Kambibi, E. (2014). Rebuilding the social fabric: Community counselling groups for Rwandan women with children born as a result of genocide rape. Intervention, 12(3), 393-404.

Hogwood. J. et al. (2017). "I learned who I am": Young people born from genocide rape in Rwanda and their experiences of disclosure. Fournal of Adolescent Research, 33(5), 549-570. doi: 10.1177/0743558417713302

Ingabire, M.C., Kagoyire, M.G., Karangwa, D, Ingabire, N., Habarugira, N, Jansen, A., \& Richters, A. (2017). Trauma informed restorative justice through community based sociotherapy in Rwanda. Intervention, 15(3), 241-253. doi: 10.1097/WTF.0000000000000163

Kagoyire, G., Rutayisire, T., \& Richters, A. (eds.) (2013). Narapfuye ndazuka: Ubuzima bw'abagore barokotse jenoside yakorewe Abatutsi mu Rwanda mu 1994. Bugesera Sociotherapy Program.

Kantengwa O. (2014). How motherhood triumphs over trauma among mothers with children from genocidal rape in Rwanda. Fournal of Social and
Political Psychology, 2(1), 417-434. doi: 10.5964/ jspp.v2i1.334

Kellermann, N.P.F. (2001). Transmission of Holocaust trauma: An Integrative view. Psychiatry, 64(3), 256-267. doi: 10.1521/ psyc.64.3.256.18464

Melander, M., Dahlblom, K., Jegannathan, B., \& Kullgren, G. (2016). Exploring communication of traumatic experiences from Khmer Rouge genocide survivors to their offspring: In-depth interviews with both generations. International fournal of Social Psychiatry, 62(4), 327-333. doi: 10.1177/0020764016631364

MINALOC (Ministry of Local Administration, Community Development and Social Affairs (2004). Dénombrement des Victimes du Génocide. Final report, Kigali, Rwanda. Retrieved from: http:// cnlg.gov.rw/fileadmin/templates/Publications/ denombrement_des_victimes_du_genocide_perpetre_contre_les_tutsi_avril_2004.pdf

Mukangendo, M. C. (2007). Caring for Children Born of Rape in Rwanda. In R. C. Carpenter (ed.) Born of War: Protecting Children of Sexual Violence Survivors in Conflict Zones (pp. 40-52). San Francisco, CA: Kumarian Press.

Nikuze, D. (2013). Parenting style and its psychological impact on rape born children: Case of raped survivors of the 1994 genocide perpetrated against Tutsi in Rwanda. International Fournal of Development and Sustainability, 2(2), 1084-1098.

Nowrojee, B. (1996). Shattered Lives: Sexual Violence During the Rwanda Genocide and its Aftermath. Human Rights Watch Africa.

Richters, A., \& Kagoyire, G. (eds.) (2014). Of death and rebirth: Life histories of Rwandan female genocide survivors. Torture, 24: Supplementum 1.

Richters, A. Rutayisire, T., \& Dekker, C. (2001). Care as a turning point in sociotherapy: Remaking the moral world in post-genocide Rwanda. Medische Antropologie, 22(1), 93-108.

Rutayisire, T., \& Richters, A. (2014). Everyday suffering outside prison walls: A legacy of community justice in post-genocide Rwanda," Social Science E Medicine, 120: 413-420. doi: 10.1016/j.socscimed.2014.06.009

Sarabwe, E., Richters, A., \& Vysma, M. (2018). Marital conflict in the aftermath of genocide in Rwanda: An explorative study within the context of community based sociotherapy, Intervention, 16(1), 14-21. doi: 10.1097/ WTF.0000000000000147

Torgovnik, J. (2009). Intended consequences: Rwandan children born of rape. New York: Aperture Foundation. 
Umulisa, C. (2009). In-between mothers: Intersectional analysis of life situation of mothers of children born as a result of rape during the 1994 Rwandan genocide. MA thesis (unpublished) Erasmus University Rotterdam, the Netherlands.

Wax, E. (2004). Rwandans are struggling to love children of hate. Washington Post, March 28. Retrieved from: http://01fe00c.netsolhost.com/images/Rwanda-28-Mar-04-Rwandans_Are_Struggling_To_Love_Children_of_Hate.pdf

Zraly, M., Rubin, S.E., \& Mukamana, D. (2013). Motherhood and resilience among Rwandan genocide-rape survivors. Ethos, 41(4), 411-439. doi: 10.1111/etho.12031 